\title{
On Studying the Interrelationships amongst the Various Barriers to e-health Services in Developing Countries like India
}

\author{
Remica Aggarwal \\ Recventures Education \\ Services Private Limited \\ Delhi, India
}

\author{
Bina Dharilal Aggarwal \\ Recventures Education \\ Services Private Limited \\ Delhi, India
}

\author{
Lakshay Aggarwal \\ Recventures Education \\ Services Private Limited \\ Delhi, India
}

\begin{abstract}
Present paper deals with first recognising various barriers to $e$-health services particularly in developing country like India. Thereafter, it studies the possible inter-relationships amongst them using ISM methodology.
\end{abstract}

\section{Keywords}

e-health; ISM Methodology

\section{INTRODUCTION}

Health systems in low and middle income countries continue to face considerable trouble in providing high quality, affordable and universally accessible care [1]. According to global survey by GOe (Global Observatory by E-Health) the strong growth of $e$-health started since 2000 [3]. Developed countries higher and middle income groups are more advanced in their e-health development. The developing nations still need special attention to ensure their proper development. Policy makers, donors and program implementers are putting efforts for innovative approaches to eliminate the geographic and financial barriers to health. In this context, many health program implementers are exploring the extent to which $m$-health can help in facing the challenges. It has been observed that there has been an unprecedented increase in the number of users of cell phone and internet technologies, as well as a decline in the price of devices and services, so this information can be well utilized in the implementation of e-health [4]. For example, with more than 900 million cell phone connections, India is the second largest mobile market in the world after China. Hence mobile phones can be considered as an efficient way to tap the online services like $e$-health. To date, the literature on e-health in low and middle income countries has largely consisted of articles describing single uses of technology in health care delivery [2]. Developing countries are faced with many problems in the healthcare and medical services such as limited financial resources, lack of trained personnel, reach ability to remote locations, etc. The reason may include various interrelated factors such as poverty, malnutrition, poor hygiene, living environment, gender or caste based discrimination.

\subsection{E-Health in Indian Context}

India is a vast country consisting of 28 states and 7 union territories. Health is the primary responsibility of each state and there is paucity of infrastructure and dearth of doctors in rural areas. A survey by the Indian medical society has found that
$75 \%$ of qualified consulting doctors practice in urban centres and $23 \%$ in semi urban areas and only $2 \%$ from rural areas whereas majority of the patients come from rural areas [10]. Besides, there is no national health insurance scheme in the country. India has emerged as the leader in telemedicine with 380 plus telemedicine centres operating across the country for providing healthcare services to remote areas but unfortunately the percentage of active services are very less. Out of many challenges like poor reach of ICT services in rural areas, low literacy leading to low awareness, insufficient infrastructure, poverty, poor data management is also one of the major deterrents to large scale adoption of e-health. Efforts are directed towards setting up standards and IT enabled healthcare infrastructure in the country. Government, administrative bodies and the different players in the health service system are looking for innovative solutions to make health services most efficient and secure. In spite of many problems, it is heartening to note that India is among those developing nations, where the progress in $e$-health has been encouraging. On this front, India is much better placed than other developing countries. According to CHMI report, a number of technology enabled programs in health care are emerging in all lower-income countries.

\subsection{Recent Projects in E-health}

- Cloud Enabled E-health Center:- India's first fully integrated cloud based $e$-health center was launched on $1^{\text {st }}$ December 2012 at the Chausala village in Haryana Kaithal District. It was a joint effort of Council of Scientific Research and Industrial Research (CSIR) and Hewlett Packard. the sole aim of the project was to provide affordable health services to remote areas.

- Virtual Medical Kiosk:- E-health Access Pvt. Ltd, a healthcare based company launched Virtual Medical Kiosk in November 2012, which enables patient doctor consultation in a secure environment. Patients and doctors can communicate through phone, web cams, video conferencing, messaging or chat.

- RFID Individual Tracking and Records Management (RFID-ITRM) e-health project at Ahmedabad, Gujarat. This $e$ - health project is central to preventing medical errors, identifying victims of natural disasters, and tracking and monitoring diseases and outbreaks, as well as infants and vaccination history.

- E-health Project at Punjab:- An e-health clinic was established in Punjab in Malwa region. A Hyderabad based NGO Naandi Foundation played a major role in launching this project. In this regard, the ministry of health \& family welfare and the ministry of communication and information 
technology are jointly creating a national health information infrastructure for easy capture and dissemination of health information [6,7].

The NHP is a Union Ministry of Health and Family Welfare Project. The portal is intended to plug in the healthcare gaps through the effective use of IT. It will establish a national database for the medical records of all the citizens from birth to death. The three main objectives of NHP are:-

--To improve the health awareness among the masses India.

---Improvement in the access to health services across the country.

---Decrease the burden of disease by educating people on the preventive aspects of disease.

The paper is organised as follows. Section 2 provides the literature review. Section 3 presents the ISM methodology. Section 4 provides the case example .

\section{LITERATURE REVIEW ON CHALLENGES TO E- HEALTH SERVICES}

The main aim behind promotion of e-Health is to try to provide a modern, up to-date and quality healthcare service to far flung corners of India where the formal medical facilities are either totally absent or of poor quality. Other major benefits include continuous training of medical and paramedical personnel, to bring awareness about the latest advances in medical field. The improvement in overall quality of healthcare personnel will benefit the entire local population. Despite the increased interest, in low and middle income countries the e-health field is still relatively nascent. To date, the literature on $e$-health in low and middle income countries has largely consisted of articles describing single uses of technology in health care delivery [1]. Developing countries are faced with many problems in the healthcare and medical services such as limited financial resources, lack of trained personnel, reach ability to remote locations, etc. The reason may include various interrelated factors such as poverty, malnutrition, poor hygiene, living environment, gender or caste based discrimination etc. According to [5] a model was designed considering the problems and challenges of $e$-health in developing countries.

Some of the biggest issues [3-10] which are hindering widespread deployment of $e$-health are:-

2.1 Lack of infrastructure [LoI] : To support e-health services, huge investments are required in basic infrastructure to ensure reliable power supply, proper road network and adequately fast Internet connectivity. Unfortunately in a developing country like India, there is insufficient availability of basic infrastructure. The power supply is unreliable even in major cities while over a hundred thousand villages are not connected to power grid.

2.2 Lack of technically competency [LTC] : A society which wants to use the ICT tools needs to have a general level literacy. In additional to medical training, the personnel involved in healthcare system from specialist doctors to low level staff, need to build competency in IT tools. In order to maximize the benefits of e-health solutions, everybody, from top managers to workers in the field, should be familiar with the technical aspects.

2.3 Lack of Financial support [LFS] : As per World Bank analysis, the developed countries spend an average of
$11 \%$ of their GDP on Health related services while this figure is only $6 \%$ for developing countries [8]. This clearly demonstrates the challenge of funding new initiative in Health care in developing countries. There is a need to allocate a regular fund in budget for improving the systems involved in $e$-health. E-health combined with proper ICT tools has the potential to serve a larger proportion of population with latest medical knowledge with lower average cost per person.

2.4 Lack of awareness of $\boldsymbol{e}$-health [LoA] : Even the top of the pyramid Doctors are not familiar with e-medicine tools and usage. So the lack of awareness of people of developing countries towards ICT innovations and methods, is one of the biggest impediments towards wide spread roll out of e-health. Even when heath care information is disseminated via ICT initiatives, the general public is still ignorant of its benefits.

2.5 Security Issues [SI] : The ICT tools and systems used for $e$-health are prone to the same security threats as other online applications. The problem is more pronounced for e-health systems as utmost privacy, safety and anonymity of information regarding patients, doctors and line of treatment is required. All the stakeholders involved in $e$-Heath, specially the patients, must have utmost confidence that their privacy is fully secure and will not be compromised due to a security breach.

2.6 Legal Issues [LI] : The absence of a coherent and clear law about $e$-health is also one of the major problems. Systematic and coordinated development of ICT initiatives requires such a legal framework. So far we don't have dedicated $e$-health and telemedicine laws in India. The first Telemedicine project in India started in year 2000 without the establishment of legal protocols.

2.7 Social and cultural factors [SCF]: Education of $e$ health services, disbelief of people in new services, resistance against change due to habits . In India, the Centre for Development of Advanced Computing (CDAC) is developing and promoting computers that are capable of multilingual support.

2.8 Interoperability [IO] : Interoperability between $e$ health operations within an institution, a region, a country or internationally requires standardization. As the level of standardization increases, more and more developers will get involved and the users will have a greater choice of off-the-shelf components without worrying about interoperability.

2.9 Lack of government strategies [LGS] : Lack of comprehensive and national strategies regarding $e$ health.

2.10 Lack of budget and finance [LBF]: Need for investment and allocation of regular budget in e-health field . Developing countries should focus on e-health, in their strategic plan of nation- wide heath care, and subsequently the e-health services. According to World Bank figures, expenditure on health in developed countries is 11 percent of their GDP as compared to just $6 \%$ on an average for developing countries [8].

2.11 Naive Environment [NE] : Lack of coverage of various regions in using medical equipment. 


\section{INTERPRETIVE STRUCTURAL MODELLING METHODOLOGY}

Suggested by Warfield [11], ISM works with the following steps: It starts with identifying the relevant elements and pairwise establishing the contextual relationship amongst them. Thereafter, a structural self-interaction matrix (SSIM) may be developed between two variables i.e. $i$ and $j$ establishing a "Lead to" relationship between criteria. Four symbols viz. V, $\mathrm{A}, \mathrm{X} \& \mathrm{O}$ are used for establishing the relationships. After that, a level partition matrix can be obtained based on establishing the precedence relationships and arranging the elements in a topological order. A Mic-Mac analysis is performed categorizing the variables in to autonomous, dependent, driver and linkage category. Finally, a diagraph can be obtained.

\section{CASE EXAMPLE}

The 09 barriers viz. Financial illiteracy [FILL];Poor Client Retention [PCR]; Loan Default [LD]; Language Barrier [LB]; Late Payments [LP]; Geographic Factors [GF] ; Poor Debt Management [PDM]; Negligence of Urban Poor [NUP]; High
Interest Rate [HIR] described in section 3.1 and 05 success factors viz. Transparency of Interest Rates [TOR]; Proper Regulation [PR]; Encourages Rural Penetration [ERP]; Field supervision [FS] and Complete range of products [CRP] described in section 3.2 has been studied further to determine the possible inter-relationships amongst them using ISM methodology .

\subsection{Construction of Structural self- interaction Matrix (SSIM)}

This matrix gives the pair-wise relationship between two variables i.e. $i$ and $j$ based on VAXO. SSIM has been presented below in Fig 1.

\subsection{Construction of Initial Reachability Matrix and final reachability matrix}

The SSIM has been converted in to a binary matrix called the initial reachability matrix shown in fig. 2 by substituting V, A, $\mathrm{X}, \mathrm{O}$ by 1 or 0 as per the case. After incorporating the transitivity, the final reachability matrix is shown below in the Fig 3.

\begin{tabular}{|l|l|l|l|l|l|l|l|l|l|l|l|l|l|}
\hline S. No. & Barriers & 1 & 2 & 3 & 4 & 5 & 6 & 7 & 8 & 9 & 10 & 11 \\
\hline & & LoI & LTC & LFS & LoA & SI & LI & SCF & I & LGS & LBF & NE \\
\hline 1 & LoI & & V & V & V & V & V & V & V & V & V & V \\
\hline 2 & LTC & & & A & A & V & X & X & X & A & X & A \\
\hline 3 & LFS & & & & V & V & V & A & V & A & A & A \\
\hline 4 & LoA & & & & & V & V & A & V & A & A & A \\
\hline 5 & SI & & & & & & X & A & A & A & A & A \\
\hline 6 & LI & & & & & & & A & A & A & A & A \\
\hline 7 & SCF & & & & & & & & V & A & A & A \\
\hline 8 & IO & & & & & & & & & A & A & A \\
\hline 9 & LGS & & & & & & & & & & V & V \\
\hline 10 & LF & & & & & & & & & & & X \\
\hline 11 & NE & & & & & & & & & & & \\
\hline
\end{tabular}

Fig 1: SSIM matrix for pair wise relationship amongst barriers

\begin{tabular}{|c|c|c|c|c|c|c|c|c|c|c|c|c|}
\hline S. No. & Barriers & 1 & 2 & 3 & 4 & 5 & 6 & 7 & 8 & 9 & 10 & 11 \\
\hline & & LoI & LTC & LFS & LoA & SI & LI & SCF & IO & LGS & LBF & $\mathrm{NE}$ \\
\hline 1 & LoI & 1 & 1 & 1 & 1 & 1 & 1 & 1 & 1 & 1 & 1 & 1 \\
\hline 2 & LTC & 0 & 1 & 0 & 0 & 1 & 1 & 1 & 1 & 0 & 1 & 0 \\
\hline 3 & LFS & 0 & 1 & 1 & 1 & 1 & 1 & 0 & 1 & 0 & 0 & 0 \\
\hline 4 & LoA & 0 & 1 & 0 & 1 & 1 & 1 & 0 & 1 & 0 & 0 & 0 \\
\hline 5 & SI & 0 & 0 & 0 & 0 & 1 & 1 & 1 & 0 & 0 & 0 & 0 \\
\hline 6 & LI & 0 & 1 & 0 & 0 & 1 & 1 & 0 & 0 & 0 & 0 & 0 \\
\hline 7 & SCF & 0 & 1 & 1 & 1 & 1 & 1 & 1 & 1 & 0 & 0 & 0 \\
\hline 8 & IO & 0 & 1 & 0 & 0 & 1 & 1 & 0 & 1 & 0 & 0 & 0 \\
\hline 9 & LGS & 0 & 1 & 1 & 1 & 1 & 1 & 1 & 1 & 1 & 1 & 1 \\
\hline 10 & LF & 0 & 1 & 1 & 1 & 1 & 1 & 1 & 1 & 0 & 1 & 1 \\
\hline 11 & $\mathrm{NE}$ & 0 & 1 & 1 & 1 & 1 & 1 & 1 & 1 & 0 & 1 & 1 \\
\hline
\end{tabular}

Fig 2: Initial reachability matrix 


\begin{tabular}{|l|l|l|l|l|l|l|l|l|l|l|l|l|l|}
\hline $\begin{array}{l}\text { S. } \\
\text { No. }\end{array}$ & Barriers & 1 & 2 & 3 & 4 & 5 & 6 & 7 & 8 & 9 & 10 & 11 & D.P \\
\hline & & LoI & LTC & LFS & LoA & SI & LI & SCF & IO & LGS & LBF & NE & \\
\hline 1 & LoI & 1 & 1 & 1 & 1 & 1 & 1 & 1 & 1 & 1 & 1 & 1 & 11 \\
\hline 2 & LTC & 0 & 1 & 1 & 1 & 1 & 1 & 1 & 1 & 0 & 1 & 1 & 9 \\
\hline 3 & LFS & 0 & 1 & 1 & 1 & 1 & 1 & 1 & 1 & 0 & 0 & 0 & 7 \\
\hline 4 & LoA & 0 & 1 & 0 & 1 & 1 & 1 & 1 & 1 & 0 & 0 & 0 & 6 \\
\hline 5 & SI & 0 & 1 & 1 & 1 & 1 & 1 & 1 & 1 & 0 & 0 & 0 & 7 \\
\hline 6 & LI & 0 & 1 & 0 & 0 & 1 & 1 & 1 & 0 & 0 & 0 & 0 & 4 \\
\hline 7 & SCF & 0 & 1 & 1 & 1 & 1 & 1 & 1 & 1 & 0 & 1 & 0 & 8 \\
\hline 8 & IO & 0 & 1 & 0 & 0 & 1 & 1 & 1 & 1 & 0 & 1 & 0 & 6 \\
\hline 9 & LGS & 0 & 1 & 1 & 1 & 1 & 1 & 1 & 1 & 1 & 1 & 1 & 10 \\
\hline 10 & LF & 0 & 1 & 1 & 1 & 1 & 1 & 1 & 1 & 0 & 1 & 1 & 9 \\
\hline 11 & NE & 0 & 1 & 1 & 1 & 1 & 1 & 1 & 1 & 0 & 1 & 1 & 9 \\
\hline & De.P & 1 & 11 & 8 & 9 & 1 & 1 & 1 & 10 & 2 & 7 & 5 & \\
\end{tabular}

Fig 3 : Final reachability matrix

D.P : Driving power; De.P : Dependence power

\subsection{Level Partition}

From the final reachability matrix, reachability and final antecedent set for each factor are found. The elements for which the reachability and intersection sets are same are the top-level element in the ISM hierarchy. After the identification of top level element, it is separated out from the other elements and the process continues for next level of elements. Reachability set, antecedent set, intersection set along with different level for elements have been shown below in table 1 .

Table 1: Iteration I

\begin{tabular}{|c|c|c|c|c|}
\hline $\begin{array}{l}\text { S. } \\
\text { No. }\end{array}$ & $\begin{array}{l}\text { Reachability } \\
\text { set }\end{array}$ & Antecedent set & $\begin{array}{l}\text { Intersectio } \\
\text { n set }\end{array}$ & Level \\
\hline 1. & $2,5,6,7$ & $\begin{array}{l}1,2,3,4,5,6,7,8, \\
9,10,11\end{array}$ & $2,5,6,7$ & \multirow{8}{*}{ I } \\
\hline 2. & $2,5,6,7,8$ & $\begin{array}{l}1,2,3,4,5,7,8,9, \\
10,11\end{array}$ & $2,5,7,8$ & \\
\hline 3. & $2,4,5,6,7,8$ & $\begin{array}{l}1,2,3,4,5,7,8,9 \\
10,11\end{array}$ & $2,4,5,7,8$ & \\
\hline 4. & $2,3,4,5,6,7,8$ & $\begin{array}{l}1,2,3,5,7,9,10,1 \\
1\end{array}$ & $2,3,5,7$ & \\
\hline 7. & $\begin{array}{l}2,3,4,5,6,7,8, \\
10\end{array}$ & $1,2,7,9,10,11$ & $2,7,10$ & \\
\hline 8. & $\begin{array}{l}2,3,4,5,6,7,8, \\
10,11 \\
\end{array}$ & $1,2,9,10,11$ & $2,10,11$ & \\
\hline 9. & $\begin{array}{l}2,3,4,5,6,7,8,9, \\
10,11\end{array}$ & 1,9 & 9 & \\
\hline 10. & $\begin{array}{l}1,2,3,4,5,6,7,8, \\
9,10,11\end{array}$ & 1 & 1 & \\
\hline
\end{tabular}

Table 2: Iteration II

\begin{tabular}{|c|c|c|c|c|}
\hline $\begin{array}{l}\text { S. } \\
\text { No. }\end{array}$ & $\begin{array}{l}\text { Reachability } \\
\text { set }\end{array}$ & Antecedent set & $\begin{array}{l}\text { Intersectio } \\
\text { n set }\end{array}$ & Level \\
\hline 2. & 8 & $1,3,4,8,9,10,11$ & 8 & \multirow{7}{*}{ II } \\
\hline 3. & 4,8 & $1,3,4,8,9,10,11$ & 4,8 & \\
\hline 4. & $3,4,8$ & $1,3,9,10,11$ & 3 & \\
\hline 7. & $3,4,8,10$ & $1,9,10,11$ & 10 & \\
\hline 8. & $3,4,10,11$ & $1,9,10,11$ & 10,11 & \\
\hline 9. & $\begin{array}{l}3,4,8,9,10, \\
11\end{array}$ & 1,9 & 9 & \\
\hline 10. & $\begin{array}{l}1,3,4,8,9,10, \\
11\end{array}$ & 1 & 1 & \\
\hline
\end{tabular}

Table 3: Iteration III

\begin{tabular}{|c|c|c|c|c|}
\hline $\begin{array}{l}\text { S. } \\
\text { No. }\end{array}$ & $\begin{array}{l}\text { Reachability } \\
\text { set }\end{array}$ & Antecedent set & $\begin{array}{l}\text { Intersectio } \\
\text { n set }\end{array}$ & Level \\
\hline 3. & 4 & $1,3,4,9,10,11$ & 4 & \multirow{6}{*}{ III } \\
\hline 4. & 3,4 & $1,3,9,10,11$ & 3 & \\
\hline 7. & $3,4,10$ & $1,9,10,11$ & 10 & \\
\hline 8. & $3,4,10,11$ & $1,9,10,11$ & 10,11 & \\
\hline 9. & $3,4,9,10,11$ & 1,9 & 9 & \\
\hline 10. & $1,3,4,9,10,11$ & 1 & 1 & \\
\hline
\end{tabular}

Table 4: Iteration IV

\begin{tabular}{|l|l|l|l|l|}
\hline $\begin{array}{l}\text { S. } \\
\text { No. }\end{array}$ & $\begin{array}{l}\text { Reachability } \\
\text { set }\end{array}$ & Antecedent set & $\begin{array}{l}\text { Intersectio } \\
\text { n set }\end{array}$ & Level \\
\hline 4. & $\mathbf{3}$ & $1,3,9,10,11$ & 3 & \\
\cline { 1 - 4 }. & 3,10 & $1,9,10,11$ & 10 & \multirow{2}{*}{ IV } \\
\cline { 1 - 4 } 8. & $3,10,11$ & $1,9,10,11$ & 10,11 & \\
\hline 9. & $3,9,10,11$ & 1,9 & 9 & \\
\cline { 1 - 4 } 10. & $1,3,9,10,11$ & 1 & 1 & \\
\cline { 1 - 3 }
\end{tabular}

Table 5: Iteration V

\begin{tabular}{|l|l|l|l|l|}
\hline $\begin{array}{l}\text { S. } \\
\text { No. }\end{array}$ & $\begin{array}{l}\text { Reachability } \\
\text { set }\end{array}$ & Antecedent set & $\begin{array}{l}\text { Intersectio } \\
\text { n set }\end{array}$ & $\begin{array}{l}\text { Leve } \\
\text { l }\end{array}$ \\
\hline 7. & 10 & $1,9,10,11$ & 10 & \multirow{2}{*}{ V } \\
\hline 8. & $\mathbf{1 0 , 1 1}$ & $1,9,10,11$ & 10,11 & \\
\hline 9. & $9,10,11$ & 1,9 & 9 & \\
\hline 10. & $1,9,10,11$ & 1 & 1 & \multicolumn{2}{|c}{} \\
\hline
\end{tabular}

Table 6: Iteration VI

\begin{tabular}{|l|l|l|l|l|}
\hline $\begin{array}{l}\text { S. } \\
\text { No. }\end{array}$ & $\begin{array}{l}\text { Reachability } \\
\text { set }\end{array}$ & Antecedent set & $\begin{array}{l}\text { Intersectio } \\
\text { n set }\end{array}$ & $\begin{array}{l}\text { Leve } \\
\text { l }\end{array}$ \\
\hline 9. & $\mathbf{9}$ & 1,9 & 9 & \multirow{2}{*}{ VI } \\
\hline 10. & 1,9 & 1 & 1 & \\
\hline
\end{tabular}

Table 7: Iteration VII

\begin{tabular}{|l|l|l|l|l|}
\hline $\begin{array}{l}\text { S. } \\
\text { No. }\end{array}$ & $\begin{array}{l}\text { Reachability } \\
\text { set }\end{array}$ & Antecedent set & $\begin{array}{l}\text { Intersectio } \\
\text { n set }\end{array}$ & $\begin{array}{l}\text { Leve } \\
\text { l }\end{array}$ \\
\hline 10. & $\mathbf{1}$ & 1 & 1 & VII \\
\hline
\end{tabular}




\subsection{Dependence Power- Driving Power}

\section{Diagram}

\begin{tabular}{|c|c|c|c|c|c|c|c|c|c|c|c|c|}
\hline \multirow{13}{*}{$\begin{array}{l}\text { Driving } \\
\text { power } \\
\Rightarrow \\
\Rightarrow\end{array}$} & 11 & LoI & Driving & & & & & & \multicolumn{2}{|l|}{ Linkage } & & \\
\hline & 10 & & LGS & & & & & & & & & \\
\hline & 9 & & & & & $\mathrm{NE}$ & & LBF & & & & LTC \\
\hline & 8 & & & & & & & & & & & SCF \\
\hline & 7 & & & & & & & & LFS & & & SI \\
\hline & 6 & & & & & & & & & LoA & $\mathrm{IO}$ & \\
\hline & 5 & & & & & & & & & & & \\
\hline & 4 & & \multicolumn{2}{|c|}{ Autonomous } & & & & & & & & LI \\
\hline & 3 & & & & & & & & \multicolumn{2}{|c|}{ Dependent } & & \\
\hline & 2 & & & & & & & & & & & \\
\hline & 1 & & & & & & & & & & & \\
\hline & & 1 & 2 & 3 & 4 & 5 & 6 & 7 & 8 & 9 & 10 & 11 \\
\hline & Dep & lence & & & & & & & & & & \\
\hline
\end{tabular}

\section{LITERARY RECOMMENDATIONS}

- The success of $e$-health is dependent upon the extent to which consumers can get online. The challenges in $e$-health will not stop the stake-holders to move ahead. There is a strong belief that health care stakeholders and the Government will work together to overcome the current obstacles [10].

- $\quad$ Ministry of Health and family welfare, Government of India has been working hard to develop a National Policy on Telemedicine and e-health. Funding and technical assistance has also been received from the external agencies such as World Health Organization (WHO)[1].

- $\quad$ The wide deployment of secured $e$-health is need of the hour, which shall definitely help us travel towards a healthy India.

\section{ACKNOWLEDGEMENTS}

Co-author Remica Aggarwal extend her sincere thanks to Prof. S.P. Singh, DMS, IIT Delhi for disseminating knowledge about ISM Methodology.

\section{REFERENCES}

[1] Bulletin of the World Health Organization (2012), 90, 332-340. DOI: 10.2471/BLT.11.099820

[2] http://www.who.int/GOe

[3] Mishra, S.K., Gupta, D., Kaur, J. 2007. Telemedicine in India: Initiatives and vision, 9th International Conference on E-health Networking Applications and services, Taipei, 81-83.

[4] Srivastava, A. E-health in developing countries: Pitfalls, challenges and possibilities. http: Ilwww.ehealthmagazine.com

[5] E-health Magazine, http://ehealth.eletsonline.com/2013/06/govt-to-launchnationalhealth-portal(2013)

[6] Hinske, S. Ray, P. 2007. Management of e-health network for disease control: A global Perspective, Proceedings of Health-com, 9th International Conference on e-Health Networking, Application and Services, Taipei , $52-57$.

[7] Center for Health Market Innovations. Pesinet. Washington: CHMI; 2010. http://healthmarketinnovations.org/program/pesinet

[8] Wickramasinghe, N.S., Fadlalla, A.M.A, Geisler, E., Schaffer, J.L. 2005. A framework for accessing $e$-Health preparedness , International Journal of Electronic Healthcare, 1(3), 316-334

[9] http://www.telemedicineindia.com/

[10] Bedi, B.S. 2003. Telemedicine in India: Initiatives and Perspective, e-health, addressing the digital divide. http://www.isro.org/scripts/telemedicine.aspx

[11] Warfield, J.N. 1974. Developing interconnection matrices in structural modelling, in the proceedings of IEEE Transactions on System, Man, and Cybernetics, SMC, 4 (1), 81-87. 